\begin{tabular}{l} 
KONSTAN \\
JURNAL FISIKA DAN PENDIDIKAN FISIKA \\
Volume 4, Nomor 1, Juni 2019 \\
$\begin{array}{r}\text { E-ISSN : } 2460-9129 \text { dan P-ISSN }: 2460-9110 \\
\text { http://jurnalkonstan.ac.id/index.php/jurnal }\end{array}$ \\
\hline
\end{tabular}

\title{
PENGARUH PENGGUNAAN LKS BERBASIS INKUIRI TERBIMBING MATERI ELASTISITAS DAN HUKUM HOOKE TERHADAP HASIL BELAJAR SISWA
}

\author{
Kartika Nurcahyati $^{1 *}$, I Wayan Distrik ${ }^{1}$, Ismu Wahyudi ${ }^{1}$ \\ ${ }^{1}$ Pendidikan Fisika Universitas Lampung, Jl. Prof. Dr. Sumantri Brojonegoro No. 1 Kota \\ Bandar Lampung, Lampung, Indonesia
}

\section{Info Artikel}

Sejarah Artikel:

Diterima Desember

2018

Disetujui Juli 2019

Dipublikasikan Juli

2019

\section{RETRACTED}

This article has been retracted as a result of multiple publications from the article by the relevant author. Similar article can be found at Pascal (Journal of Physics and Science Learning) Vol. 2, No. 2 with url https://jurnal.uisu.ac.id/index.php/PASCAL/article/view/936

(C) 2019 Universitas Islam Negeri Mataram

\section{Kata Kunci:}

LKS, inkuiri terbimbing,

hasil belajar

* Corresponding Author: jurnalkonstan@uinmataram.ac.id

Alamat korespodensi:

Gedung Pasca Sarjana Lantai 3 Kampus 2 UIN Mataram, Jl. Gajah Mada 100 Jempong Mataram, Indonesia

Email: jurnalkonstan@uinmataram.ac.id 